\title{
USGS Emergency Response Resources
}

Every day, emergency responders are confronted with worldwide natural and manmade disasters, including earthquakes, floods, hurricanes, landslides, tsunami, volcanoes, wildfires, terrorist attacks, and accidental oil spills. The U.S. Geological Survey
(USGS) is ready to coordinate the provisioning and deployment of USGS staff, equipment, geospatial data, products, and services in support of national emergency response requirements.

http://www.usgs.gov/

\section{USGS Real-Time Information}

Earthquakes Situational awareness tools include e-mail and text alerts to over 200,000 subscribers, and the Prompt Assessment of Global Earthquakes for Response (PAGER) system's rapid estimates of casualties and economic losses.

PAGER: Rapid estimate of fatalities/economic impact http://earthquake.usgs.gov/earthquakes/pager

Volcanoes The USGS uses a common nationwide alert/notification system for characterizing the level of unrest and eruptive activity at the sites of the 169 active U.S. volcanoes, including threats to aviation and nearby communities.

Landslides The USGS conducts landslide hazard assessments, pursues landslide investigations and forecasts, provides technical assistance to respond to landslide emergencies, and engages in outreach activities. The USGS is partnering with the National Oceanic and Atmospheric Administration (NOAA) on a prototype debris-flow warning system for wildfire-impacted areas of southern California.

Flooding The USGS collects and distributes real-time streamflow data for 7,700 streamgages, provides onsite hydrologic expertise to the National Weather Service river forecast centers during major floods, deploys field crews to measure flood flows at streamgages and other locations of interest, performs highwater surveys for analysis of flood flows, and deploys water-level monitors to record hurricane storm surge.

USGS floods Web site

http://water.usgs.gov/floods

Current flood conditions and flood-data portal water.usgs.gov/floods/current
Did you feel it?

http://earthquake.usgs.gov/earthquakes/dyfi

Earthquake Notification Service (sign up for e-mail/text)

https://sslearthquake.usgs.gov/ens/
U.S. volcano alerts

http://volcanoes.usgs.gov/activity/status.php

Volcano status map

http://volcanoes.usgs.gov/activity/index.php

\section{Advisories}

http://landslides.usgs.gov/advisories/

Monitoring

http://landslides.usgs.gov/monitoring

WaterAlert: Customized flood notification e-mails and messages http://water.usgs.gov/wateralert/

StreaMail: Instant text message of current conditions http://ga.water.usgs.gov/streamail/streamail-help.html

Summary of recent flooding (map and tabular data) http://waterwatch.usgs.gov/new/index.php?id=wwdp2_2 http://water.usgs.gov/floods/past.html

National Flood Hazard Coordinator

Robert R. Holmes, Jr.

E-mail: bholmes@usgs.gov

Telephone: (573) 308-3581

\section{USGS Flood and Hurricane Databases}

The USGS maintains extensive datasets and statistical summaries of riverine flooding that can be accessed for historical context and preparation and assessment of FEMA flood-insurance rate maps. Storm-surge water-level and barometric-pressure data are useful for assessing past flooding and calibration of storm-surge models.

Storm-surge data, maps, and reports

http://water.usgs.gov/osw/programs/storm_surge.html
USGS peak flow file

http://nwis.waterdata.usgs.gov/usa/nwis/peak

Flood hydrographs

http://ida.water.usgs.gov/ida/index_usgs.cfm

Regional flood-frequency equations

http://water.usgs.gov/software/NSS/

Flood-frequency estimates for ungaged locations

http://water.usgs.gov/osw/streamstats/ 
GeoMAC This is a Web-based mapping application that provides current geospatial information on the status, location, and proximity of wildfires to natural resources, property, and infrastructure. This application, originally designed for fire managers to strategically place firefighting resources, has become increasingly popular with the public. http://www.geomac.gov

Rapid Data Delivery System (RDDS) provides emergency and incident response teams with timely access to geospatial data.

http://rmgsc.cr.usgs.gov/rdds

The National Map is easily accessible for display on the Web, as products and services, and as downloadable data. The geographic information available from The National Map includes orthoimagery (aerial photographs), elevation, geographic names, hydrography, boundaries, transportation, structures, and land cover.

http://nationalmap.gov/

The National Geospatial Technology Operations Center (NGTOC) administers a set of Indefinite Delivery Indefinite Quantity (IDIQ) contracts, which provide a mechanism to procure geospatial data acquisition and other professional geospatial services. There are seven prime contractors and multiple subcontractors providing an extensive range of capabilities and flexible capacity throughout the United States. See http://geodatacontracts.er.usgs.gov/ for more information about the USGS Geospatial Products and Services Contracts (GPSC).
The NGTOC also provides bulk downloads of geospatial data from The National Map, including USGS Topographic Maps, for emergency response. Contact Larry Moore at 303-202-4019 or lmoore@usgs.gov.

US Topo provides 1-meter imagery no older than 3 years, hydrography, transportation, structures, boundaries, geographic names, and the U.S. National Grid.

http://nationalmap.usgs.gov/ustopo

Hazard Data Distribution System (HDDS) is the preeminent source for disaster imagery. HDDS provides services for pre-event baseline imagery and data, and the most recent event/disaster response imagery and data.

http://hdds.usgs.gov/hdds2/

LANDFIRE (Landscape Fire and Resource Management Planning Tools) is an interagency program, led by USGS, that delivers a comprehensive, consistent, and scientifically credible suite of geospatial data products that describe vegetation and fuel characteristics for the United States based on field referenced data and imagery from the Landsat.

LANDFIRE provides geospatial data products that are used in national strategic planning for risk management, wildfire decision support, and resource allocation before, during, and after wildfires. www.landfire.gov

\section{USGS Offices Supporting Emergency Response}

Key Senior Executives at USGS National Center and Regional Offices.

http://www.usgs.gov/aboutusgs/organized/key_officials.asp

National Earthquake Information Center provides 24/7 monitoring and reporting of earthquakes in the United States and worldwide. http://earthquake.usgs.gov/regional/neic/

Volcano Science Centers are five USGS volcano observatories (Alaska, Cascades, Hawaii, Long Valley, and Yellowstone) that monitor and issue alerts and warnings for the 169 active volcanoes in the United States. http://volcanoes.usgs.gov/index.php

National Landslide Information Center provides technical assistance to respond to landslide emergencies.

http://landslides.usgs.gov/nlic/

USGS Water Science Centers located in each State, provide technical assistance for emergency measurement, monitoring, and analysis of floods, and sampling of chemical spills.

http://water.usgs.gov/district_chief.html

National Geospatial Program, Office of Natural Hazards Response and Geospatial Data Delivery provides emergency response support to the Department of Homeland Security, United States Northern Command, and the National Geospatial-Intelligence Agency. In addition, the Office of Natural Hazards Response and Geospatial Data Delivery coordinates the acquisition and provision of satellite imagery and authoritative geospatial information for use in disaster preparations, rescue and relief operations, damage assessments, and reconstruction efforts.

USGS Geospatial Liaisons, as part of the National Geospatial Program's Partnership Network, coordinate geospatial data acquisition and use with State and Federal emergency management officials and first responders. http://liaisons.usgs.gov/geospatial/

Eastern Region Geographic Science Center provides imagery and geospatial analyses, GIS, and mapping expertise in support of the Department of the Interior's Interior Operations Center and Web-based decision support tool development in partnership with other Federal agencies. http://egsc.usgs.gov/
Special Applications Science Center provides imagery and geospatial analysis, and geospatial support for hurricanes, flooding, and wildland fire response. Contact Thomas W. Owens, Center Director, at tom_owens@usgs.gov.

Earth Resources Observation and Science (EROS) Center provides satellite imagery, elevation data, and climate data to support emergency operations.

http://eros.usgs.gov/

National Wetlands Research Center provides Science Response Vehicle (SRV) deployment, SRV staffing, GIS, and mapping support http://www.nwrc.usgs.gov/

National Water-Quality Laboratory provides rapid analysis of waterquality contamination following a chemical spill, as needed. http://nwql.usgs.gov/

Crustal Geophysics and Geochemistry Science Center provides analytical capability to examine environmental contamination resulting from disasters.

http://crustal.usgs.gov/index.html

Coastal and Marine Geology Science Centers monitor and predict magnitudes of erosion of U.S. coasts during extreme storms, and support modeled assessments of storm surge.

http://marine.usgs.gov/index.php

USGS Environmental Health provides data, research, and diagnostic methodologies on disaster-related health issues involving contaminants and pathogens, including specialized expertise in zoonotic diseases of wildlife such as avian influenza.

http://www.usgs.gov/envirohealth/

\section{For more information, please contact:}

Robert Bewley, U.S. Geological Survey

590 National Center, 12201 Sunrise Valley Drive

Reston, VA 20192

703-648-5660

rbewley@usgs.gov 